Article

\title{
Evoking Agriculture Entrepreneurship: How Younger and Older Farmers Differ
}

\author{
Chao-Chien Chen ${ }^{1}$ and Chaoyun Liang ${ }^{2, *}$ (i) \\ 1 Smartagri Integration Service Co., Ltd., Taipei 116059, Taiwan; markchen1204@gmail.com \\ 2 Department of Bio-Industry Communication and Development, National Taiwan University, \\ Taipei 10617, Taiwan \\ * Correspondence: cliang@ntu.edu.tw
}

Received: 25 June 2020; Accepted: 24 August 2020; Published: 27 August 2020

check for updates

\begin{abstract}
This study examined the agriculture entrepreneurial intentions (AEIs) of current farmers $(n=1183)$ in Taiwan and distinguished differences between $\leq 45$ - and $>45$-year-old farmers by applying the theory of planned behaviour with the extension of personality traits. The results determined that the entrepreneurial commitment and communication aspects of entrepreneurial self-efficacy (ESE) considerably affected the conviction dimension of AEI, whereas entrepreneurial commitment, communication ESE, entrepreneurial attitude, planning ESE, and neuroticism notably influenced the preparation dimension of AEI. Furthermore, the effects of neuroticism on entrepreneurial conviction were weaker in younger farmers than in older farmers, and the effects of entrepreneurial commitment, entrepreneurial attitude, neuroticism, and planning ESE on entrepreneurial preparation in younger farmers were different from those in older farmers. Moreover, length of agricultural engagement exhibited an inverted U-shaped curvilinear relationship with AEIs. The present study contributes to the understanding of how younger farmers' AEIs can be shaped and how they may cope with the differences they may have compared with older family members.
\end{abstract}

Keywords: agriculture entrepreneurial intentions; entrepreneurial attitude; entrepreneurial commitment; entrepreneurial self-efficacy; length of agricultural engagement; personality traits

\section{Introduction}

Global warming has negatively affected the physical and biological systems of human society. Human society must simultaneously consider the ecological, ethical, and social dimensions of future agricultural practices and uses of rural landscapes [1]; hence, agricultural multifunctionality and new venture activities are in demand. In this vein, multifunctional and related startups have contributed to transforming rural living, natural environments, and economic diversity for Asian nations, including Taiwan [2]. Over the years, agriculture entrepreneurship has been extensively discussed, but the discourse regarding the image of agricultural careers has changed rapidly in recent years. An emerging topic in agricultural multifunctionality is the demand for younger people with new ideas and farming entrepreneurship to address how agribusinesses can respond to rural development $[3,4]$. Attracting younger people to agricultural careers in rural areas demands clarifying the reason that they leave [5]. Numerous rural youths rationalise leaving rural areas by acknowledging the reality that the resources they require to self-empower and acquire financial wealth are unavailable to them, even with farm succession [6,7]. Scholars identified problems young farmers confront and made policy recommendations to address them, such as creating opportunities, encouraging land mobility, addressing further barriers to new entrants, offering specific supports, and pursuing implemented measures [8]. Agricultural multifunctionality also provides potential niches because agricultural activity has multiple functions that shape the landscape and afford environmental benefits; examples 
include land conservation for the function of producing food, sustainable management of renewable natural resources, and contribution to the socioeconomic viability of rural areas [4]. However, although studies have focused on agriculture entrepreneurship [9], many open questions on this topic require clarification. The efforts and benefits of such an agricultural reform, as well as the resources and capabilities required for achieving this reform, are insufficiently understood, particularly regarding the contribution of entrepreneurship to agricultural economic development [10].

Taiwan has a firmly established infrastructure in agriculture, strong research and development capability, and agricultural extension services [11]. With its rapid industrial development over previous decades, the economic power of Taiwan has increased substantially but its agricultural contribution has declined. Numerous farmers are currently deprived of economic opportunities, fair employment, and access to essential services [12]. The agricultural management system in Taiwan is primarily that of small-scale farms. Thus, accumulating capital, increasing investment, and expanding the scale of operations are challenging; consequently, farmers lack bargaining power for their product prices [13]. Taiwan has numerous flexible modes of operation to address this limitation. Recent development trends in rural areas, such as the establishment of farmers' markets and the promotion of agricultural tourism and entrepreneurial ventures, have revitalised rural culture in small towns in Taiwan. The government is also eager to facilitate agriculture entrepreneurship and farmer cooperation as an economic scale for competing with agricultural products in the world market [13].

Globally or locally, agriculture entrepreneurship has become critical to promoting increased food productivity, environmental sustainability, and ecological diversity. Encouraging younger people to return to rural areas to engage with farming work is crucial to achieving agriculture entrepreneurship. In addition to the provision of desirable resources, a thorough understanding of how younger farmers' agriculture entrepreneurial intentions (AEIs) are shaped, and helping them narrow the gap regarding rural startups with older family members, are indispensable. Therefore, the present study examined the AEIs of current farmers in Taiwan to distinguish differences between younger (aged $\leq 45$ years) and older (aged $>45$ years) farmers using the theory of planned behaviour (TPB) [14]. Additionally, personality traits and length of agricultural engagement were considered because recent studies have reported a strong relationship between personality traits and entrepreneurship $[15,16]$ and because relevant research has suggested that length of rural engagement affects intention towards rural practice $[17,18]$.

\section{Literature Review}

Research regarding intention formation is an initial effort towards a broader understanding of entrepreneurship [19]. As a conceptual extension of the theory of reasoned action, TPB is the most widespread theory of intention formation. TPB theorises the influences of attitude towards behaviour, subjective norms, and perceived behavioural control through the mediation of intentions for predicting people's behaviour in certain circumstances. Studies have repeatedly confirmed that these three variables contribute to a prediction of the willingness of individuals to perform a behaviour [20]. In the present study, AEI can be conceptualised as having two aspects: AE conviction and AE preparation [21-23].

Attitude towards behaviour is defined as a favourable or unfavourable predisposition towards an intended behaviour [14]. In other words, an individual's behaviour is a reflection of that person's attitude and who the person is, consistent with Zig Ziglar's quote: "Your attitude, not your aptitude, will determine your altitude." Therefore, entrepreneurial attitude can be perceived as an individual's perception towards the value, belief, benefit, attractiveness, and favourability of entrepreneurship [24]. Entrepreneurial attitude is a robust explanatory factor for career choice and commitment because it influences an individual's confidence, enthusiasm, inclination, and aspiration towards entrepreneurship [25]. The more positive the entrepreneurs' attitude towards startups, the greater would be their commitment. Entrepreneurial commitment refers to the extent to which an entrepreneur identifies with and is engaged in a new business [26]. In other words, entrepreneurial 
attitude lays a foundation for a farmer to initiate a new agribusiness, and entrepreneurial commitment sustains the business-initiating action. Therefore, in this study, attitude towards a behaviour is measured as "entrepreneurial attitude" and "entrepreneurial commitment". Therefore, the first two hypotheses were proposed:

Hypothesis 1 (H1). Entrepreneurial attitude positively and directly influences AEI.

Hypothesis 2 (H2). Entrepreneurial commitment positively and directly influences AEI.

Subjective norms represent assumptions that a given behaviour is more or less expected by people the decision-maker considers important [14]. They also represent the social pressures experienced by an individual to perform a particular behaviour but have an influence that is generally weaker than that of attitude [27]. Several studies have confirmed that people have a tendency to present a behaviour respected by their reference groups, and subjective norms have significant causal paths towards a particular behaviour [27-29]. Human intentions are more heavily influenced by personal factors, such as attitudes and perceived behavioural control, than by contextual factors [14]. This argument has been supported by several studies reporting weak correlation between subjective norms and behavioural intentions $[30,31]$. Then, the third hypothesis was proposed:

Hypothesis 3 (H3). Subjective norms negatively and directly influence AEI.

Perceived behavioural control refers to expectation of the ease or difficulty of performing a particular behaviour [14]. Perceived control over performance of a particular behaviour encompasses components that reflect beliefs about self-efficacy (dealing largely with the difficulty of performing a behaviour) and controllability (the extent to which performance is up to the actor) [32]. High self-efficacy" people believe they exercise control over their thoughts and actions. Self-efficacy often inspires entrepreneurs' confidence in their abilities as grander than those of others and as enabling greater successes [23]. Entrepreneurial self-efficacy (ESE) can be measured using several dimensions: searching (involving opportunity identification and development), marshalling (involving assembling resources to bring the venture into existence), planning (to convert the idea into a feasible business plan), and implementing (ensuring the growth and sustainability of the venture) [33]. By contrast, controllability significantly predicts actual behaviour but has no effect on intentions, but the effects resulting from self-efficacy are not vice versa [34]. Several subsequent studies have determined that controllability has little or no effect on intention or target behaviour [35-37]. Therefore, we proposed the fourth hypothesis:

Hypothesis 4 (H4). ESE positively and directly influences AEI.

In addition, recent research has reported strong associations between personality traits and entrepreneurship $[15,16,23,38,39]$. The five-factor model (FFM) is a widely accepted personality model [15]. The FFM structure comprises the five dimensions of extroversion (traits associated with sociability, self-assurance, and talkativeness), openness (associated with preferring variety, being broad-minded, and exhibiting intellectual curiosity), neuroticism (traits associated with experiencing negative emotional states such as depression, anxiety, sadness, fear, and anger), conscientiousness (traits associated with a person's degree of hard work, self-control, organization, and active planning in accomplishing goals), and agreeableness (traits associated with being compassionate, warm, friendly, considerate, and willing to cooperate in conflict situations). Entrepreneurs typically have high scores for extraversion, openness, and conscientiousness and comparatively low scores on neuroticism and agreeableness. Furthermore, relevant research has suggested that length of rural engagement affects intention towards rural practice $[17,18]$, revealing the longer a rural engagement, the stronger the intention towards rural practice. However, the effect of work engagement on behavioural intention 
may be nonlinear $[40,41]$. On the basis of these insights, personality traits and length of agricultural engagement were considered in this study, and four additional hypotheses were proposed:

Hypothesis 5 (H5). Extraversion, openness, and conscientiousness positively and directly influence AEI.

Hypothesis 6 (H6). Neuroticism and agreeableness negatively and directly influence AEI.

Hypothesis 7 (H7). The AEI predictive model for younger farmers is different from that for older farmers.

Hypothesis 8 (H8). Length of agricultural engagement has a curvilinear relationship with AEI.

\section{Confirmatory Factor Analysis}

\subsection{Research Samples}

In this study, 1083 valid samples were collected through online surveys to investigate the factors and their influences on the AEIs of farmers currently engaged in agricultural production in Taiwan. The samples were initially used to perform confirmatory factor analysis (CFA) to verify the factor structure of the observed variables and then used to test the proposed model by employing a structural equation modelling (SEM) methodology to examine the causal relationships among the variables. The researchers subsequently divided the samples into two groups: younger (aged $\leq 45$ years; $n=554$ ) and older (aged $>45$ years; $n=529$ ) farmers. The criterion of 45 years was set according to instruction issued by the Council of Agriculture in Taiwan [42]. All participants were informed that the survey was confidential, anonymous, and voluntary and that they had the right to review the results of their responses.

\subsection{Research Tools}

This questionnaire contained six subscales: (1) demographic variables (basic data such as gender, age, and years of agricultural engagement); (2) AEI [21,23] (the 10-item subscale examined participants' intention towards agriculture entrepreneurship); (3) entrepreneurial attitude and commitment [20,43] (this 10-item subscale inspected participants' attitude and commitment regarding agriculture entrepreneurship); (4) subjective norms [44] (this five-item subscale assessed participants' perceptions of subjective norms); (5) ESE [33] (this 15-item subscale investigated participants' ESE towards agriculture entrepreneurship); and (6) personality traits [45] (the International English Big-Five Mini-Markers was adopted). Of the 40 adjectives in the original personality trait model, the 20 with the highest factor loadings were selected as items.

The questionnaire comprised single-response questions, rated on a 6-point scale: $1=$ strongly disagree; 2 disagree; $3=$ slightly disagree; $4=$ partly agree; $5=$ agree; and $6=$ strongly agree. The 6-point design was based on the suggestions of quantitative researchers [46]. Missing answers to questions were deemed missing data. The questionnaire conformed to international scale standards and was repeatedly verified to ensure the validity and reliability of each item.

\subsection{Research Process and Descriptive Analysis}

Data collection was accomplished using an online questionnaire on the SurveyCake survey platform (https://www.surveycake.com/tw/). We promoted the questionnaire through several domestic farmer organisations in various regions of the country to augment participation. The front page of the questionnaire listed the research objective and the respondents' rights. Moreover, we declared that the data would be anonymised for subsequent data analysis to ensure the confidentiality of their responses. The demographic variables of the investigated farmers were described using descriptive analysis with SPSS, version 21 (IBM, Armonk, NY, USA); CFA and SEM analyses were conducted 
using LISREL, version 9.1 (Scientific Software International, Inc, Skokie, IL, USA). Table 1 reports the descriptive analysis results.

Table 1. Descriptive analysis $(n=1083)$.

\begin{tabular}{|c|c|c|c|c|}
\hline Demographic Variables & \multicolumn{4}{|c|}{ Sample Number (\%) } \\
\hline Gender & \multicolumn{2}{|c|}{$\begin{array}{c}\text { Men } \\
683(63.07 \%)\end{array}$} & \multicolumn{2}{|c|}{$\begin{array}{c}\text { Women } \\
400(36.93 \%)\end{array}$} \\
\hline \multirow[b]{2}{*}{ Age } & \multicolumn{4}{|c|}{$M=43.46 ; S D=11.64$} \\
\hline & \multicolumn{2}{|c|}{$\begin{array}{c}45 \text { years or younger } \\
554(51.15 \%)\end{array}$} & \multicolumn{2}{|c|}{$\begin{array}{c}46 \text { years or older } \\
529(48.85 \%)\end{array}$} \\
\hline $\begin{array}{c}\text { Length of agricultural } \\
\text { engagement }\end{array}$ & $\begin{array}{l}0-1.99 \text { years } \\
513(47.37 \%)\end{array}$ & $\begin{array}{l}2-4.99 \text { years } \\
293(27.05 \%)\end{array}$ & $\begin{array}{c}6-14.99 \text { years } \\
184(16.99 \%)\end{array}$ & $\begin{array}{c}15 \text { years and longer } \\
93(8.59 \%)\end{array}$ \\
\hline
\end{tabular}

\section{Analysis Results}

\subsection{CFA}

In the current study, AEI was conceptualised as having two aspects: AE conviction and AE preparation [23]. AE conviction refers to the personal appeal of starting a social enterprise, whereas $\mathrm{AE}$ preparation refers to the degree to which one is prepared to do so. In addition, we simplified the five dimensions of ESE [33] to three concepts: "planning", "communication", and "implementation" because "searching" and "planning" tasks are often performed simultaneously, the items of "marshalling" are apt to "communication", and "implementing (people)" and "implementing (financial)" can be combined as "implementation". Furthermore, personality can be categorised as five traits: neuroticism, extraversion, agreeableness, conscientiousness, and openness to experience.

The validity of the factor structures was ensured by performing CFA with maximal likelihood estimation. The goodness of fit of each subscale was evaluated according to Tabachnick and Fidell [47], revealing an excellent level. The composite reliability of each factor was greater than 0.6 [48]; convergent validity was tested against the standardised factor loadings [49]; discriminant validity was tested by calculating the confidence intervals of the interfactor correlation estimates, which should not include 1 [50]. Composite reliability, convergent validity, and discriminant validity all reached the established standards. Table 2 reports the CFA results, including factor loadings, composite reliability, and average variance extracted.

Table 2. Confirmatory factor analysis (CFA) results $(n=1083)$.

\begin{tabular}{|c|c|c|c|c|c|c|c|c|c|c|c|c|c|}
\hline \multirow{2}{*}{$\begin{array}{c}\text { Variable } \\
\text { Item } \backslash \text { Factor }\end{array}$} & \multirow{2}{*}{ Eatt } & \multirow{2}{*}{ Ecom } & \multirow{2}{*}{ Snor } & \multicolumn{3}{|c|}{ ESE } & \multicolumn{5}{|c|}{ PT } & \multicolumn{2}{|c|}{ AEI } \\
\hline & & & & Pla & Com & $\operatorname{Imp}$ & Neu & Ext & Agr & Con & Ope & AEc & AEp \\
\hline 1 & 6 & & 24 & 0.821 & 2 & 0 & 0.675 & 0.743 & 0.747 & 0.827 & 0.699 & 0.927 & 0.942 \\
\hline 2 & 876 & & 0.816 & 0.871 & 0.874 & 0.855 & 0.8 & 0.860 & 0.728 & 0.8 & 0.7 & 0.932 & 0.930 \\
\hline 3 & 0.881 & 0.867 & 0.866 & 0.888 & 0.867 & 0.859 & 0.759 & 0.864 & 0.719 & 0.898 & 0.874 & 0.891 & 0.954 \\
\hline 4 & 0.882 & 0.857 & 0.802 & 0.876 & 0.790 & 0.786 & 0.620 & 0.822 & 0.806 & 0.825 & 0.838 & 0.933 & 0.950 \\
\hline 5 & 0.884 & 0.714 & 0.612 & 0.816 & 0.849 & 0.798 & - & - & - & - & - & 0.887 & 0.895 \\
\hline CR & 0.926 & 0.897 & 0.884 & 0.931 & 0.929 & 0.903 & 0.809 & 0.895 & 0.836 & 0.916 & 0.871 & 0.957 & 0.972 \\
\hline AVE & 0.719 & 0.688 & 0.601 & 0.728 & 0.725 & 0.700 & 0.517 & 0.683 & 0.561 & 0.731 & 0.628 & 0.849 & 0.873 \\
\hline
\end{tabular}

Note: Eatt = entrepreneurial attitude; Ecom = entrepreneurial commitment; Snor = subjective norms; Pla = planning self-efficacy; Com = communication self-efficacy; Imp = implementation self-efficacy; PT = personality traits; $\mathrm{Neu}=$ neuroticism $; \mathrm{Ext}=$ extraversion; $\mathrm{Agr}=$ agreeableness; $\mathrm{Con}=$ conscientiousness; $\mathrm{Ope}=$ openness to experience; $\mathrm{AEc}=\mathrm{AE}$ conviction; $\mathrm{AEp}=\mathrm{AE}$ preparation; $\mathrm{CR}=$ composite reliability; $\mathrm{AVE}=$ average variance extracted.

\subsection{SEM for All Participants}

The proposed hypotheses were tested with the same data from 1083 samples using an SEM approach with maximal likelihood estimation. The effects of subjective norms, implementation 
self-efficacy, and extraversion, agreeableness, conscientiousness, and openness were nonsignificant; thus, their coefficient paths were removed from the subsequent test. The final results indicated that the model fit was excellent $\left(\chi^{2}=1287.41, d f=445, p<0.005\right.$, RMSEA $=0.043$, SRMR $=0.039$, CFI $=0.966$, $\mathrm{NFI}=0.950, \mathrm{NNFI}=0.963$ ).

Figure 1 illustrates that entrepreneurial attitude positively and directly influenced AE preparation, but had no effect on AE conviction, thus partially supporting H1. Entrepreneurial commitment positively and directly influenced both dimensions of AEI, thus supporting $\mathrm{H} 2$. No significant effects of subjective norms were found on AEI; hence, $\mathrm{H} 3$ was rejected. Regarding ESE, the planning dimension influenced only AE preparation but not $\mathrm{AE}$ conviction; the communication dimension influenced both $\mathrm{AE}$ preparation and $\mathrm{AE}$ conviction; and no effects resulted from the implementation dimension, all therefore partially supporting H4. Regarding personality traits, the effects of extraversion, openness, and conscientiousness on AEI were nonsignificant; hence, $\mathrm{H} 5$ was rejected. Only neuroticism exerted marginal effects on AEI; thus, H6 was partially supported. Table 3 reports the correlation coefficients and effects of latent variables.

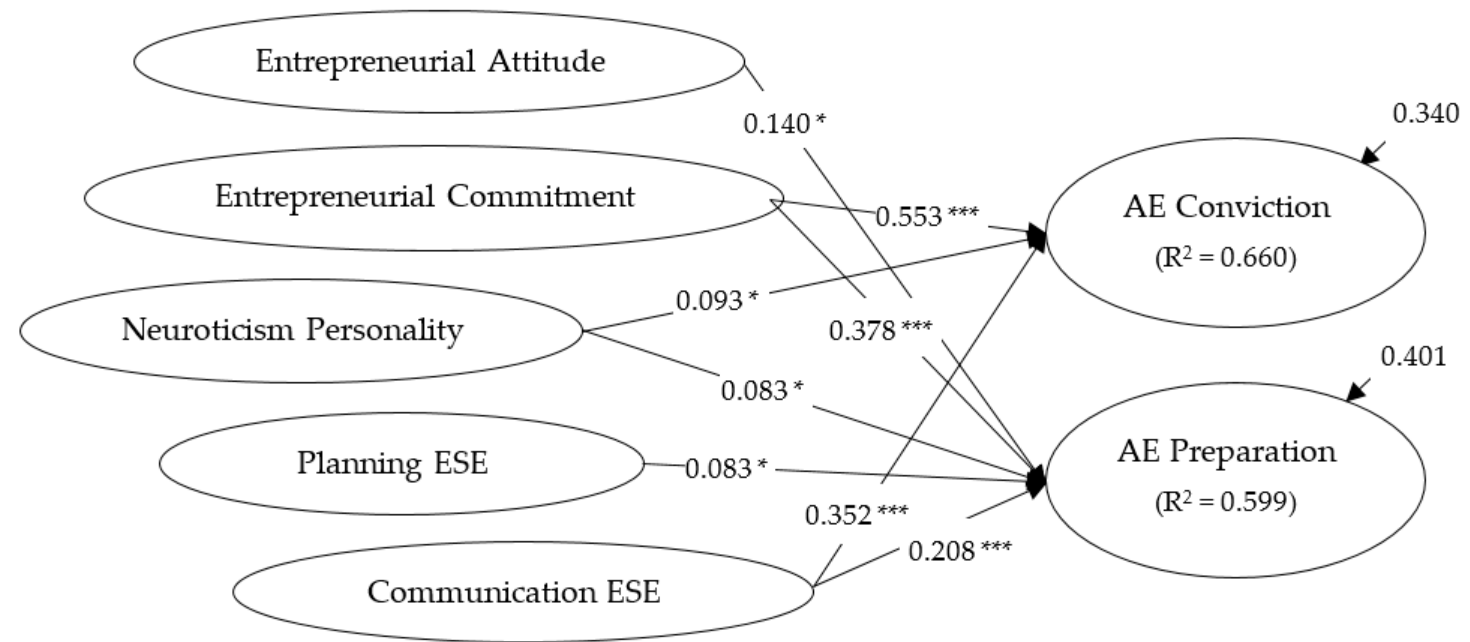

Figure 1. Structural equation modelling (SEM) for all samples $(n=1083) ;{ }^{*} p<0.05,{ }^{* * *} p<0.001$.

Table 3. Correlation coefficients and effects of latent variables $(n=1083)$.

\begin{tabular}{|c|c|c|c|c|c|c|c|}
\hline \multirow[b]{2}{*}{ Variables } & \multirow[b]{2}{*}{ Eatt } & \multirow[b]{2}{*}{ Ecom } & \multirow[b]{2}{*}{ Pla } & \multirow[b]{2}{*}{ Com } & \multirow[b]{2}{*}{ Neu } & \multicolumn{2}{|c|}{ AEI } \\
\hline & & & & & & $\begin{array}{c}\mathrm{AE} \\
\text { Conviction }\end{array}$ & $\begin{array}{c}\text { AE } \\
\text { Preparation }\end{array}$ \\
\hline Entrepreneurial Attitude (Eatt) & - & & & & & - & 0.140 \\
\hline Entrepreneurial Commitment (Ecom) & 0.791 & - & & & & 0.553 & 0.378 \\
\hline Planning ESE (Pla) & 0.577 & 0.578 & - & & & - & 0.083 \\
\hline Communication ESE (Com) & 0.564 & 0.575 & 0.740 & - & & 0.352 & 0.208 \\
\hline Neuroticism Personality (Neu) & -0.077 & -0.049 & 0.032 & 0.030 & - & 0.093 & 0.083 \\
\hline
\end{tabular}

The results of regression analyses (Figure 2) indicated that length of agricultural engagement exhibited an inverted U-shaped curvilinear relationship with both dimensions of AEI. Therefore, H8 was supported. Table 4 reports the regression analysis results. 

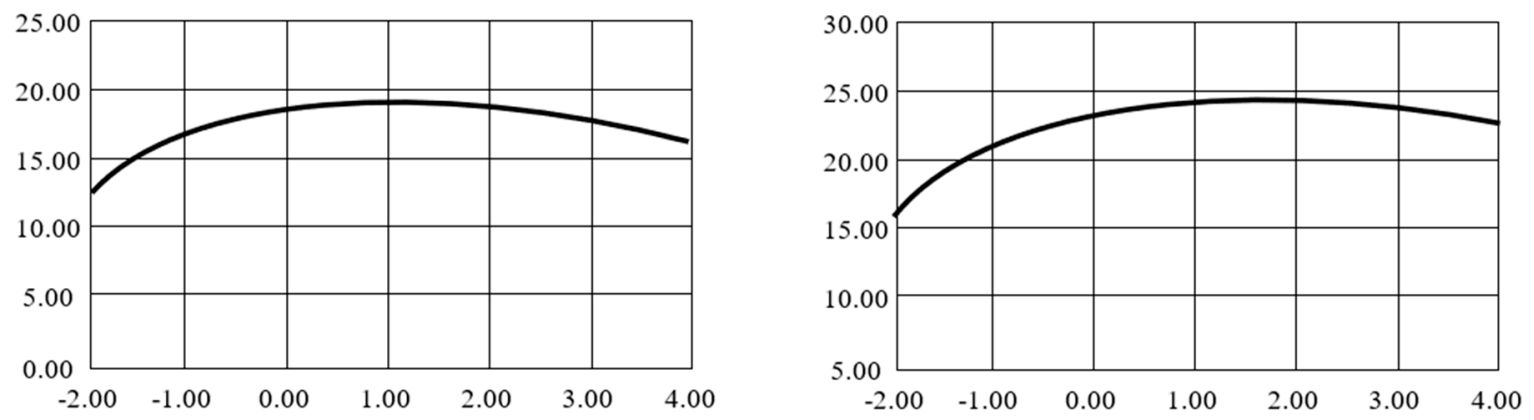

Figure 2. Curvilinear relationship of length of agricultural engagement with agriculture entrepreneurial (AE) conviction (left) and AE preparation (right) $(n=1083)$.

Table 4. Regression analyses of length of agricultural engagement on agriculture entrepreneurial intentions (AEI) $(n=1083)$.

\begin{tabular}{|c|c|c|c|c|c|c|c|}
\hline \multirow{2}{*}{\multicolumn{2}{|c|}{ Variable }} & \multicolumn{3}{|c|}{ AE Conviction } & \multicolumn{3}{|c|}{ AE Preparation } \\
\hline & & Beta & $t$ & $p$ & Beta & $t$ & $p$ \\
\hline \multicolumn{2}{|c|}{ (constant) } & & 105.541 & $0.000^{* * *}$ & & 96.322 & $0.000^{* * * *}$ \\
\hline \multirow{2}{*}{\multicolumn{2}{|c|}{ Length of agricultural engagement $(\mathrm{Y})$}} & 0.447 & 9.147 & $0.000 * * *$ & 0.437 & 8.884 & $0.000^{* * *}$ \\
\hline & & -0.263 & -5.467 & $0.000^{* * * *}$ & -0.299 & -6.088 & $0.000^{* * *}$ \\
\hline \multirow{3}{*}{ Model summary } & $R^{2}$ & \multicolumn{3}{|c|}{0.078} & \multicolumn{3}{|c|}{0.069} \\
\hline & $\mathrm{F}$ & \multicolumn{3}{|c|}{46.620} & \multicolumn{3}{|c|}{40.917} \\
\hline & $p$ & \multicolumn{3}{|c|}{$0.000^{* * *}$} & \multicolumn{3}{|c|}{$0.000^{* * *}$} \\
\hline
\end{tabular}

\subsection{SEM for Younger Farmers}

H7 was tested by dividing the sample into two groups: younger and older farmers. The SEM results (Figure 3) revealed that the model fit was excellent $\left(\chi^{2}=1123.95, d f=445, p<0.005\right.$, RMSEA $=0.054$, $\mathrm{SRMR}=0.049, \mathrm{CFI}=0.951, \mathrm{NFI}=0.922, \mathrm{NNFI}=0.946)$. The correlation coefficients and effects of latent independent variables are detailed in Table 5 .

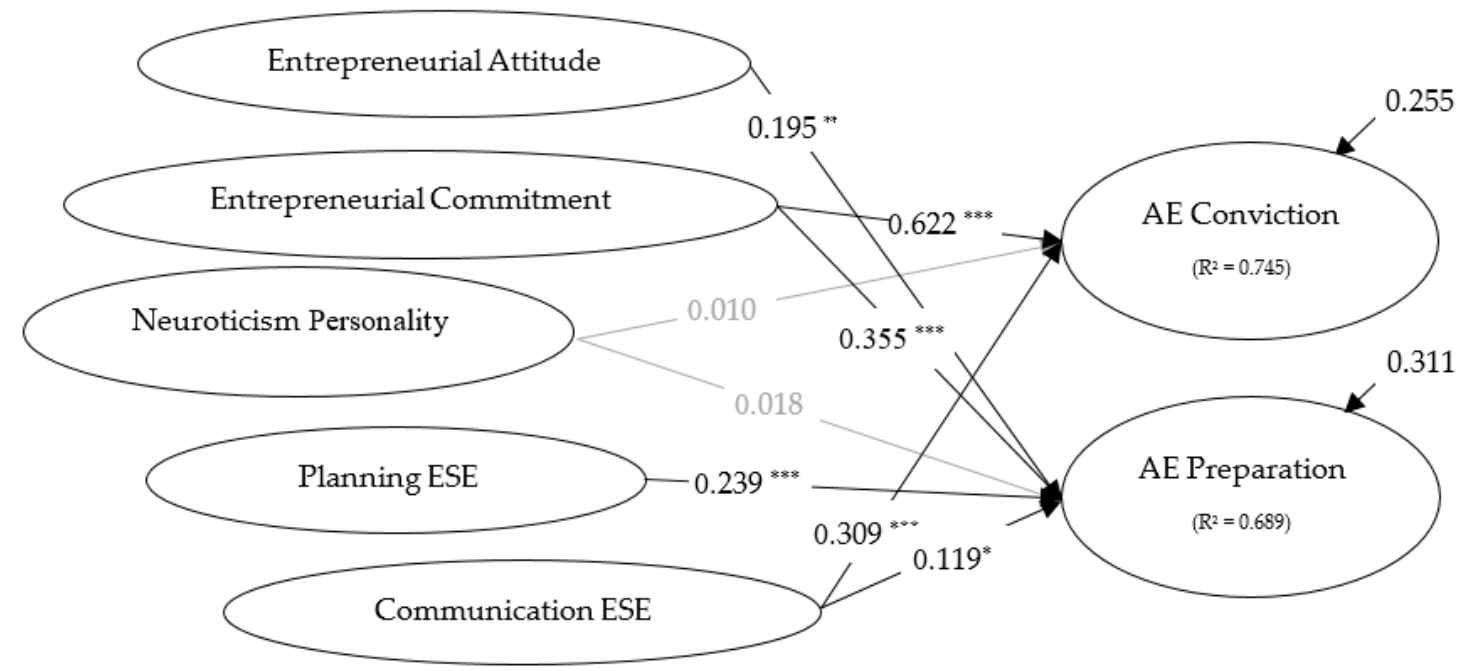

Figure 3. SEM for younger farmers $(n=554) .{ }^{*} p<0.05,{ }^{* *} p<0.01,{ }^{* *} p<0.001$. 
Table 5. Correlation coefficients and effects of latent variables $(n=554$; younger farmers).

\begin{tabular}{|c|c|c|c|c|c|c|c|}
\hline \multirow{2}{*}{ Variables } & \multirow{2}{*}{ Eatt } & \multirow{2}{*}{ Ecom } & \multirow{2}{*}{ Pla } & \multirow{2}{*}{ Com } & \multirow{2}{*}{ Neu } & \multicolumn{2}{|c|}{ AEI } \\
\hline & & & & & & $\begin{array}{c}\mathrm{AE} \\
\text { Conviction }\end{array}$ & $\begin{array}{c}\text { AE } \\
\text { Preparation }\end{array}$ \\
\hline Entrepreneurial Attitude (Eatt) & - & & & & & - & 0.195 \\
\hline Entrepreneurial Commitment (Ecom) & 0.807 & - & & & & 0.622 & 0.355 \\
\hline Planning ESE (Pla) & -0.724 & 0.681 & - & & & - & 0.239 \\
\hline Communication ESE (Com) & 0.703 & 0.686 & 0.843 & - & & 0.309 & 0.119 \\
\hline Neuroticism Personality (Neu) & -0.066 & -0.043 & -0.007 & 0.034 & - & 0.010 & 0.018 \\
\hline
\end{tabular}

\subsection{SEM for Older Farmers}

The SEM results (Figure 4) revealed that the model fit was excellent $\left(\chi^{2}=1185.96, d f=445\right.$, $p<0.005$, RMSEA $=0.058$, SRMR $=0.043, \mathrm{CFI}=0.934, \mathrm{NFI}=0.899, \mathrm{NNFI}=0.927)$. The correlation coefficients and effects of latent independent variables are detailed in Table 6. The results further explicated the power differences for each predictor on the AEI of younger farmers and those of older farmers. Therefore, H7 was supported. The results indicated that the influences of the neuroticism trait on AE conviction among older farmers were stronger than those of younger farmers, whereas the influences of entrepreneurial commitment, entrepreneurial attitude, neuroticism, and planning ESE on their AE preparation among younger farmers were different from those among older farmers.

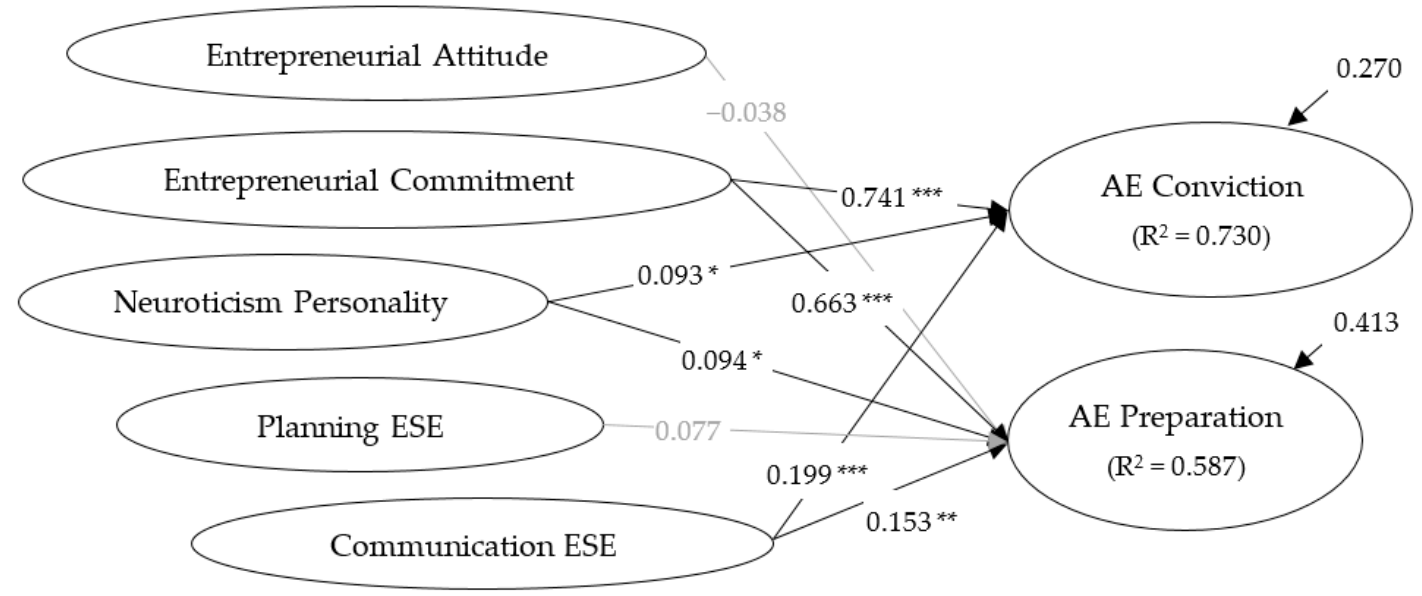

Figure 4. SEM for older farmers $(n=529) .{ }^{*} p<0.05,{ }^{* *} p<0.01,{ }^{* * *} p<0.001$.

Table 6. Correlation coefficients and effects of latent variables $(n=529$; older farmers).

\begin{tabular}{cccccccc}
\hline Variables & Eatt & Ecom & Pla & Com & Neu & \multicolumn{2}{c}{ AEI } \\
\cline { 6 - 8 } & & & & & & $\begin{array}{c}\text { AE } \\
\text { Conviction }\end{array}$ & $\begin{array}{c}\text { AE } \\
\text { Preparation }\end{array}$ \\
\hline Entrepreneurial Attitude (Eatt) & - & & & & & - & -.038 \\
Entrepreneurial Commitment (Ecom) & 0.842 & - & & & & 0.741 & 0.663 \\
$\quad$ Planning ESE (Pla) & 0.503 & 0.500 & - & & & - & 0.077 \\
Communication ESE (Com) & 0.481 & 0.476 & 0.829 & - & & 0.199 & 0.153 \\
Neuroticism Personality (Neu) & -0.034 & -0.048 & -0.009 & -0.039 & - & 0.093 & 0.094 \\
\hline
\end{tabular}

\section{Discussion}

\subsection{Overall Effects}

According to the current results, entrepreneurial commitment and communication ESE were two major factors affecting the AEI of current farmers in Taiwan. Entrepreneurial attitude only exerted its influences on AE preparation; the effects of planning ESE and neuroticism were marginal but remained significant. Over centuries, agricultural activities have induced landscapes with various seminatural habitats and species dependent on the maintenance of farming. Agricultural workers 
have a custodial responsibility for the natural resources under their control such that agribusiness operations also involve non-profit elements. Unless an entrepreneur has a positive attitude and a strong commitment towards the natural environment, they have difficulty maintaining their inclination and passion towards agriculture entrepreneurship [25]. Our results support this notion by exhibiting the dominant effects of entrepreneurial attitude and commitment on AEI.

Accordingly, communication ESE strongly affected AEI, and planning ESE had only a minor effect, whereas implementation ESE did not significantly influence AEI. The operations of many farmers differ considerably from those of farmer-entrepreneurs, explaining the reason that ESE in implementation had invisible effects on both AE conviction and AE preparation. The biological nature of agricultural production and operation is heavily affected by the natural environment, which is difficult for farmers to control. Fixed costs in farming, such as land and labour costs, are often higher than those in industry. Moreover, Taiwan has a small-scale system, and most farmers lack market power. However, market demand is typically inelastic because food is an essential good and agriculture is commonly an inherent part of a nation's culture and policies. In this complicated situation, self-efficacy in marshalling resources and networks as well as convincing others to identify with, work in, and devote themselves to agriculture inevitably becomes a golden key to pursuing self-employment.

Although the effects resulting from neuroticism on both entrepreneurial conviction and preparation were marginal, the implications may be worth discussing. In addition to the aforementioned unstable biological system, high fixed costs, lack of market power, and professional thresholds, general consumers may link food production to ethical concerns, including health concerns and food safety and quality, but few types of food production can easily and simultaneously be safeguarded, sped up, and down-costed in response to favourable market demands. Unexpected events and inexplicable pressures would push people with strong neuroticism traits to initiate tasks such as startups because people exhibiting high levels of neuroticism are prone to impulsive behaviour and to applying poor coping strategies in stressful situations $[15,23]$, which might facilitate intentions to select self-employment.

In addition, we observed an inverted U-shaped relationship between the length of agricultural engagement and AEI. The curve suggested that the positive trend dominated a wide range at most parts of the continuum of the length of agricultural engagement. Increasing duration of agricultural engagement had few benefits for stimulating AEI when the duration was prolonged, indicating that length of agricultural engagement acted as an engine for both AE belief-building and action facilitation $[17,18]$ but an extensive period of engagement may diminish entrepreneurial passion.

\subsection{Comparison between Younger and Older Farmers}

The results continually indicated that the effects of neuroticism on the entrepreneurial convictions were weaker in younger farmers than those in older farmers. This is probably because younger farmers have comparably more plentiful time for trial and error in farming and agribusiness operations, even those who possess high levels of neuroticism. However, experimentation would be perceived as more pressing, particularly for older and more neurotic farmers, and AE conviction or AE preparation would have little influence.

Accordingly, the effect of AE attitude on younger farmers' AE preparation was stronger than for older farmers, whereas the effect of AE commitment on younger farmers' AE preparation was weaker than for older farmers. Although related laws of diminishing returns in farming land and the custodial responsibility for the natural environment make it difficult for an agriculture operation to achieve economies of scale, younger farmers could be attracted back to their home villages as the older generations gradually decay. Because younger farmers would care more about the balance between agricultural production and quality of rural life, leaving urban life might strengthen their AE attitude and further benefit their entrepreneurial action. This result may imply that encouraging guidelines and workshops should be developed for younger farmers to nurture their enthusiasm, elucidate their aims, reinforce their worth, and maintain their integrity to strengthen their AE attitude. 
By contrast, the lengthy farming practices of older farmers might deepen their understanding of the contributions of agriculture for fulfilling societal goals such as maintaining the viability of rural areas, safeguarding food security, and preserving cultural heritage. Older farmers may also lack the knowledge and skills required to work in competitive urban areas. All these contribute to reducing their AE commitment. If possible, favourable policies should be set by both central and local governments for older farmers to cooperate and hold each other to high principles, encourage them to make decisions together to overcome conflict, foster feelings of success in what they do and experiencing victories together, create opportunities to celebrate and appreciate one another, and help them learn from setbacks and challenge one another to take new steps. In summary, firm commitment would greatly enhance older farmers' AEIs.

Finally, the effect of planning ESE on younger farmers' AE preparation was much stronger than on older farmers, indicating that younger farmers may be more acquainted with startup procedures and modern managerial practices than older farmers, allowing them to focus more on the benefits derived from formalising a practical business plan with realistic aims, which concurs with the outcomes of previous studies [51,52]. Furthermore, high-ESE people engaging in planning are less likely to found a venture that has limited chances of success [53]. Therefore, this result may imply that appropriate guidelines and helpful workshops should be designed for younger farmers to assist them in constructing challenging and proximal goals, setting proper task demands and expectations, developing heuristics thinking through experiential practices, enhancing self-management, providing clear feedback from experts, and modelling apposite actions. The comparison between younger and older farmers is summarised in Table 7.

Table 7. Comparison between younger and older farmers.

\begin{tabular}{ccccc}
\hline \multirow{2}{*}{ Variables } & \multicolumn{2}{c}{ Younger Farmers } & \multicolumn{2}{c}{ Older Farmers } \\
\cline { 2 - 5 } & AE Conviction & AE Preparation & AE Conviction & AE Preparation \\
\hline Entrepreneurial Attitude & - & 0.195 & - & -0.038 \\
Entrepreneurial & 0.622 & 0.355 & 0.741 & 0.663 \\
Commitment & - & 0.239 & - & 0.077 \\
Planning ESE & 0.309 & 0.119 & 0.199 & 0.153 \\
Communication ESE & 0.010 & 0.018 & 0.093 & 0.094 \\
Neuroticism Personality & & & \\
\hline
\end{tabular}

\section{Contributions and Research Limitations}

This study has at least three research limitations. First, self-reporting scales were used because they were empirically valid and easy to administer, but social desirability might have contributed to inaccuracies with such self-perception tools. Research has indicated common method bias is an overstated threat to validity [54] if a study adopts simple measures, such as the careful choice of instruments, and offers feedback. Nevertheless, other approaches should be applied for further examination. Second, this study compared younger farmers with older farmers and tested the curvilinear relationship between length of agricultural engagement and AEI, but it neither considered length of agricultural engagement in SEM analyses nor accounted for close factors such as scales and types of startup. This means that critical features of AE were not inspected and more detailed studies are required in the future. Finally, the variables examined are not certainly associated with agribusiness performance; similarly, entrepreneurial commitment and communication ESE are not necessarily linked to the efficacy or success of self-employment. These and other considerations in scrutinising the behavioural performance of farmer-entrepreneurs [55-58] warrant future inquiries.

We nevertheless conclude that entrepreneurial commitment, communication ESE, and entrepreneurial attitude strongly affect the AEI of current farmers in Taiwan, and length of agricultural engagement exhibits an inverted U-shaped curvilinear relationship with AEIs. The largest differences between younger and older farmers were in effects resulting from entrepreneurial commitment, entrepreneurial attitude, neuroticism, and planning ESE. The results provide several contributions 
to agribusiness creation and AE education. First, we evidenced that the values of entrepreneurial commitment and communication ESE contribute to AEI, which differs from previous studies. Second, we clarified differences regarding how the identified predictors shape AEI between younger and older farmers, which has rarely been studied. Third, because enhancing youth interest and career choice in AE practices is a modern societal goal related to global sustainability, this study elucidated corresponding strategies for talent development and self-assessment for AE.

We do not propose that this study provides thorough considerations towards AEI research; rather, the outcomes demonstrate that different strategies for stimulating AEI should be used with different age groups and thus narrow the identified research gap by providing a robust theoretical foundation and carefully planned survey analyses. Our findings can also serve as a reference for governmental and related organisations to formulate feasible policies and promising strategies that encourage farmers to create agricultural enterprises or to revitalise their family rural business, thus accomplishing rural sustainability and economic development simultaneously.

Author Contributions: Conceptualization and investigation, C.-C.C.; methodology and formal analysis, C.L.; writing C.-C.C. and C.L. All authors have read and agreed to the published version of the manuscript.

Funding: This research received no external funding.

Conflicts of Interest: The authors declare no conflict of interest.

\section{References}

1. Wilson, K.; Morren, G.E.B., Jr. Systems Approaches for Improvement in Agriculture and Resource Management; Macmillan: New York, NY, USA, 1990.

2. Osawa, M. Contemporary discourses on agriculture in Japan: From futureless $3 \mathrm{~K}$ to sophisticated future lifestyle in LOHAS, living in rural areas, and Hann Han-x. Bull. Grad. Div. Lit. Waseda Univ. 2014, $49,111-121$.

3. Potter, C.; Tilzey, M. Agricultural multifunctionality, environmental sustainability and the WTO: Resistance or accommodation to the neoliberal project for agriculture. Geoforum 2007, 38, 1290-1303. [CrossRef]

4. Van Huylenbroeck, G.; Vandermeulen, V.; Mettepenningen, E.; Verspecht, A. Multifunctionality of Agriculture: A Review of Definitions, Evidence and Instruments. Living Rev. Landsc. Res. 2007, 1, 5-43. [CrossRef]

5. Nugin, R. I think that they should go. Let them see something. The context of rural youth's out-migration in post-socialist Estonia. J. Rural. Stud. 2014, 34, 51-64. [CrossRef]

6. Chiswell, H. From Generation to Generation: Changing Dimensions of Intergenerational Farm Transfer. Sociol. Rural. 2016, 58, 104-125. [CrossRef]

7. Fischer, H.; Burton, R.J.F. Understanding Farm Succession as Socially Constructed Endogenous Cycles. Sociol. Rural. 2014, 54, 417-438. [CrossRef]

8. Zagata, L.; Hrabák, J.; Lošták, M.; Bavorová, M.; Ratinger, T.; Sutherland, L.-A.; McKee, A. Research for AGRI Committee-Young Farmers-Policy Implementation after the 2013 CAP Reform; Policy Department for Structural and Cohesion Policies, European Parliament: Brussels, Belgium, 2017.

9. Fuller-Love, N.; Midmore, P.; Thomas, D.; Henley, A. Entrepreneurship and rural economic development: A scenario analysis approach. Int. J. Entrep. Behav. Res. 2006, 12, 289-305. [CrossRef]

10. Grande, J. New venture creation in the farm sector-Critical resources and capabilities. J. Rural. Stud. 2011, 27, 220-233. [CrossRef]

11. Huang, W.-C.; Lin, J.-S. Urban/peri-urban agriculture: Status and challenges in Taiwan. In Proceedings of the Paper Presented at the 2006 FFTC-PCARRD International Workshop on Urban/Peri-Urban Agriculture in the Asian and Pacific Region, Tagaytay City, Philippines, 22-26 May 2006.

12. Chen, X.-C.; Chang, H.-S. Discussion on the impact factor of agricultural land in Taiwan: Case study of Yunlin, Chiayi, and Tainan. Procedia Env. Sci. 2013, 17, 28-36. [CrossRef]

13. Liang, C.; Chang, C.-C.; Liang, C.-T.; Liu, Y.-C. Imagining future success: Imaginative capacity on the perceived performance of potential agrisocio entrepreneurs. Think. Ski. Creat. 2017, 23, 161-174. [CrossRef]

14. Ajzen, I.; Joyce, N.; Sheikh, S.; Cote, N.G. Knowledge and the Prediction of Behavior: The Role of Information Accuracy in the Theory of Planned Behavior. Basic Appl. Soc. Psychol. 1991, 50, 179-211. [CrossRef] 
15. Brandstätter, H. Personality aspects of entrepreneurship: A look at five meta-analyses. Pers. Individ. Differ. 2011, 51, 222-230. [CrossRef]

16. Liang, C. How Entrepreneur Personality Affects Agrirural Entrepreneurial Alertness. J. Entrep. Manag. Innov. 2019, 15, 147-170. [CrossRef]

17. Johnston, R.J.; Swallow, S.K.; Bauer, D.M. Stated Preferences and Length of Residency in Rural Communities: Are Development And Conservation Values Heterogeneous. In Proceedings of the Annual meeting of the American Agricultural Economics Association, Long Beach, CA, USA, 28-31 July 2002.

18. Wang, J.-H.; Liang, C. Empowerment through intrinsic motivation and self-efficacy: How Personality Traits Influence Rural Practice in Agricultural students. In Personality Traits and Types: Perceptions, Gender Differences and impact On Behavior; Hawkins, J., Ed.; Nova Science Publishers: Hauppauge, NY, USA, 2015; pp. $109-132$.

19. Liu, H.-C.; Liang, C.; Chang, C.-C.; Ip, C.Y.; Liang, C.-T. Optimizing Personality Traits and Entrepreneurial Creativity to Boost the Precursors of Social Entrepreneurial Intentions: Five Studies in Taiwan. J. Soc. Serv. Res. 2020, 1-23. [CrossRef]

20. Liñán, F.; Chen, Y.-W. Testing the Entrepreneurial Intention Model on a Two-Country Sample. Doc. Treb. Núm. 2006, 6, 593-617.

21. Chang, C.-C.; Yao, S.-N.; Chen, S.-A.; King, J.-T.; Liang, C. Imagining Garage Start-Ups: Interactive Effects of Imaginative Capacities on Entrepreneurial Intention. Creat. Res. J. 2016, 28, 289-297. [CrossRef]

22. Liang, C.; Ip, C.Y.; Wu, S.-C.; Law, K.M.; Wang, J.-H.; Peng, L.-P.; Liu, H.-C. Personality traits, social capital, and entrepreneurial creativity: Comparing green socioentrepreneurial intentions across Taiwan and Hong Kong. Stud. High. Educ. 2017, 44, 1086-1102. [CrossRef]

23. Wang, J.-H.; Chang, C.-C.; Yao, S.-N.; Liang, C. The contribution of self-efficacy to the relationship between personality traits and entrepreneurial intention. High. Educ. 2015, 72, 209-224. [CrossRef]

24. Schultz, P.W.; Oskamp, S. Effort as a moderator of the attitude behaviour relationship: General environmental concern and recycling. Soc. Psychol. Q 1996, 59, 375-383. [CrossRef]

25. Robinson, P.B.; Stimpson, D.V.; Huefner, J.C.; Hunt, H.K. An Attitude Approach to the Prediction of Entrepreneurship. Entrep. Theory Pr. 1991, 15, 13-32. [CrossRef]

26. Tang, J. Environmental munificence for entrepreneurs: Entrepreneurial alertness and commitment. Int. J. Entrep. Behav. Res. 2008, 14, 128-151. [CrossRef]

27. Ham, M.; Jeger, M.; Ivković, A.F. The role of subjective norms in forming the intention to purchase green food. Econ. Res. Ekon. Istraž. 2015, 28, 738-748. [CrossRef]

28. Hall, K.; Rhoades, E. Influence of Subjective Norms and Communication Preferences on Grain Farmers' Attitudes toward Organic and Non-Organic Farming. J. Appl. Commun. 2010, 94, 5. [CrossRef]

29. Tarkiainen, A.; Sundqvist, S. Subjective norms, attitudes and intentions of Finnish consumers in buying organic food. Br. Food J. 2005, 107, 808-822. [CrossRef]

30. Ip, C.Y.; Liang, C.; Wu, S.-C.; Law, K.M.; Liu, H.-C. Enhancing Social Entrepreneurial Intentions through Entrepreneurial Creativity: A Comparative Study Between Taiwan and Hong Kong. Creat. Res. J. 2018, 30, 132-142. [CrossRef]

31. Rivis, A.; Sheeran, P. Descriptive norms as an additional predictor in the theory of planned behaviour: A meta-analysis. Curr. Psychol. 2003, 22, 218-233. [CrossRef]

32. Ajzen, I. Perceived Behavioral Control, Self-Efficacy, Locus of Control, and the Theory of Planned Behavior1. J. Appl. Soc. Psychol. 2002, 32, 665-683. [CrossRef]

33. McGee, J.E.; Peterson, M.; Mueller, S.L.; Sequeira, J.M. Entrepreneurial Self-Efficacy: Refining the Measure. Entrep. Theory Pract. 2009, 33, 965-988. [CrossRef]

34. Terry, D.J.; O'Leary, J.E. The theory of planned behaviour: The effects of perceived behavioural control and self-efficacy. Br. J. Soc. Psychol. 1995, 34, 199-220. [CrossRef]

35. Armitage, C.J.; Conner, M. Distinguishing Perceptions of Control From Self-Efficacy: Predicting Consumption of a Low-Fat Diet Using the Theory of Planned Behavior1. J. Appl. Soc. Psychol. 1999, 29, 72-90. [CrossRef]

36. Manstead, A.S.R.; Eekelen, S.A.M. Distinguishing Between Perceived Behavioral Control and Self-Efficacy in the Domain of Academic Achievement Intentions and Behaviors. J. Appl. Soc. Psychol. 1998, 28, 1375-1392. [CrossRef]

37. Sparks, P.; Guthrie, C.A.; Shepherd, R. The Dimensional Structure of the Perceived Behavioral Control Construct1. J. Appl. Soc. Psychol. 1997, 27, 418-438. [CrossRef] 
38. Zhao, H.; Seibert, S.E. The Big Five personality dimensions and entrepreneurial status: A meta-analytical review. J. Appl. Psychol. 2006, 91, 259-271. [CrossRef] [PubMed]

39. Zhao, H.; Seibert, S.E.; Hills, G.E. The Mediating Role of Self-Efficacy in the Development of Entrepreneurial Intentions. J. Appl. Psychol. 2005, 90, 1265-1272. [CrossRef] [PubMed]

40. Caesens, G.; Stinglhamber, F.; Marmier, V. The curvilinear effect of work engagement on employees' turnover intentions. Int. J. Psychol. 2014, 51, 150-155. [CrossRef]

41. Shimazu, A.; Schaufeli, W.B.; Kubota, K.; Watanabe, K.; Kawakami, N. Is too much work engagement detrimental? Linear or curvilinear effects on mental health and job performance. PLoS ONE 1996, 13, e0208684. [CrossRef]

42. Kuo, K.-F. One-Stop Service for Young Farmers in Taiwan. Available online: http://ap.fftc.agnet.org/ap_db. php?id=328 (accessed on 24 November 2019).

43. Mowday, R.T.; Steers, R.M.; Porter, L.W. The measurement of organizational commitment. J. Vocat. Behav. 1979, 14, 224-247. [CrossRef]

44. Yu, T.-L.; Wang, J.-H. Factors affecting social entrepreneurship intentions among agricultural university students in Taiwan. Int. Food Agribus. Manag. Rev. 2019, 22, 107-118. [CrossRef]

45. Thompson, E.R. Development and Validation of an International English Big-Five Mini-Markers. Pers. Individ. Differ. 2008, 45, 542-548. [CrossRef]

46. Grant, T.; Clark, U.; Reershemius, G.; Pollard, D.; Hayes, S.; Plappert, G. Quantitative Research Methods for Linguists; Informa UK Limited: London, UK, 2017; p. 35.

47. Tabachnick, B.G.; Fidell, L.S. Using Multivariate Statistics; Allyn \& Bacon: Boston, MA, USA, 2001.

48. Fornell, C.; Larcker, D. Evaluating structural equation models with unobservable variables and measurement error. J. Mark. Res. 1981, 18, 39-50. [CrossRef]

49. Hair, J.F.; Black, W.C.; Babin, B.J.; Anderson, R.E. Multivariate Data Analysis: A Global Perspective; Pearson/Prentice Hall: Upper Saddle River, NJ, USA, 2010.

50. Bagozzi, R.P.; Phillips, L.W. Representing and Testing Organizational Theories: A Holistic Construal. Adm. Sci. Q. 1982, 27, 459. [CrossRef]

51. Brinckmann, J.; Kim, S.M. Why We Plan: The Impact of Nascent Entrepreneurs' Cognitive Characteristics and Human Capital on Business Planning. Strat. Entrep. J. 2015, 9, 153-166. [CrossRef]

52. Tumasjan, A.; Braun, R. In the eye of the beholder: How regulatory focus and self-efficacy interact in influencing opportunity recognition. J. Bus. Ventur. 2012, 27, 622-636. [CrossRef]

53. Hechevarria, D.; Renko, M.; Matthews, C. The nascent entrepreneurship hub: Goals, entrepreneurial self-efficacy and start-up outcomes. Small Bus. Econ. 2012, 39, 685-701. [CrossRef]

54. Malhotra, N.K.; Kim, S.S.; Patil, A. Common Method Variance in IS Research: A Comparison of Alternative Approaches and a Reanalysis of Past Research. Manag. Sci. 2006, 52, 1865-1883. [CrossRef]

55. Coad, A.; Daunfeldt, S.-O.; Hölzl, W.; Johansson, D.; Nightingale, P. High-growth firms: Introduction to the special section. Ind. Corp. Chang. 2014, 23, 91-112. [CrossRef]

56. Henrekson, M.; Johansson, D. Gazelles as job creators: A survey and interpretation of the evidence. Small Bus. Econ. 2009, 35, 227-244. [CrossRef]

57. Kolar, J. Policies to support High Growth Innovative Enterprises; European Commission: Brussels, Belgium, 2014.

58. Musolino, D.; Senn, L. La Filiera Ferroviaria Italiana Nella Competizione Globale; Research Report; The National Federation of Italian Electrotechnical, Electronics and ICT Companies: Roma, Italy, 2011.

(C) 2020 by the authors. Licensee MDPI, Basel, Switzerland. This article is an open access article distributed under the terms and conditions of the Creative Commons Attribution (CC BY) license (http://creativecommons.org/licenses/by/4.0/). 